\title{
Local Wisdom of Minangkabau in Marriage System in Novel Mengurai Rindu By Nang Syamsuddin
}

\section{Romi Isnanda and Syofiani}

Lecturer of Indonesian Language and Literature Education Program, Department of Language and Art Education, Faculty of Teacher Training and Education, Bung Hatta University

\section{Abstract}

This study aimed to describe the local wisdom of Minangkabau in the execution of a marriage that consist of pinang-meminang(proposing), batimbang tando(engagement), pernikahan (wedding),manjapuikmarapulai(picking up the groom), and manjalang (visiting groom's family) in the novel MenguraiRindubyNang Syamsuddin. The theories used in this research are the local wisdom theory proposed by Abrams (in Kusmarwanti, 2008), Minangkabau marriage system theory presented by Navis (1986), and the

Corresponding Author:

Romi Isnanda

isnanda.romi@yahoo.com

Received: 18 January 2019

Accepted: 24 March 2019

Published: 31 March 2019

Publishing services provided by

Knowledge E

(c) Romi Isnanda and

Syofiani. This article is

distributed under the terms of

the Creative Commons

Attribution License, which

permits unrestricted use and

redistribution provided that the

original author and source are credited.

Selection and Peer-review under the responsibility of the ICEST 2018 Conference Committee. sociology of literature theory uncovered by Ratna (2014). This type of research was qualitative with descriptive method. Data in this research are words, phrases, clauses, sentences, and paragraphs that describe the local wisdoms of Minangkabau in novel MenguraiRindu by Nang Syamsuddin. The data analysis step was done by: (1) identifying data related to local wisdom of Minangkabau in novel MenguraiRindu by Nang Syamsuddin; (2) classifying the identified data; (3) analyzing data with sociology of literature approach; and (4) concluding the results of data analysis. The result of data analysis found that local wisdom of Minangkabau marriage system innovelMenguraiRindu by Nang Syamsuddin are pinang-meminang(proposing), the bride's family will come to propose the groom that the uncle of the bride will be in charge of the proposal system. Batimbangtando (engagement) is when the agreement made between two parties; those who break the vows must pay the fine as much as the first agreement multiplied two. Pernikahan(wedding), some believes that Friday is the best day to carry out the marriage contract. After the marriage ceremony, the groom will return to the home of his parents. Manjapuikmarapulai (picking up the groom), that is when the bride's family picked up the groom along with Roki (complete outfit for groom), a pair of shoes, and the existence of pasumandan (uncle's wife of the bride). Manjalang(visiting groom's family) is the procedure and tradition of watering turmeric rice on the bride during the procession of manjalang.

Keywords: local wisdom, Minangkabau, novel MenguraiRindu 


\section{Preliminary}

Literary works are works of art as a part of culture. This is because not only the work of literature is a work of culture, but also a literary work reflected the picture of human life and the social and cultural conditions that surround it. One form of literary work is novel. Novel is the author's creative product that does not depart from the social culture void. The author in creating the novel does not escape the experience of human life and the social and cultural conditions that surround it, thus allowing the culture or uniqueness of a region painted in the story (novel). The painting of regional distinctiveness in the story called the local wisdom.

Abrams (in Kusmawanti, 2008: 2) defines local wisdom as a careful painting of background, dialect, custom, dress, way of thinking, way of feeling and so forth which is typical of a particular area contained in the story. Therefore, to recognize local wisdom in literature, it is necessary to understand the philosophy and cultural ideology of the nation or region of the story actors (Kurnia, 2017: 141).

Novel contained of local wisdom generally written by authors who come from the area concerned, for example, the Minangkabau area. Authors from the Minangkabau region tend to raise the uniqueness or culture of Minangkabau itself. This is because Minangkabau is one area that has a unique culture, and interesting to be appointed as the background of the literary works (novel). Thus, the term local wisdom Minangkabau emerged.

The local wisdom of Minangkabau is a careful painting of the socio-cultural conditions of the Minangkabau community. The socio-cultural conditions of the Minangkabau community are characterized among others as seen in the system of marriage. The Minangkabau marriage system has distinctive and varied ruleson each region ofMinangkabau, depending on the local custom set in the area, as Minangkabau customary philosophy is "lain lubuk lain ikannyo, lain padang lain belalanngyo" meaning that each region has rules and differences of customs in accordance with the conditions of their respective regions and communities. However, in general there are three main events of the same marriage system carried out in all regions of the Minangkabau, namely, pernikahan(wedding), manjapuikmarapulai(picking up the groom) and manjalang (visiting the groom's family) (1986: 203). Before the wedding, there will be pinang-meminang (proposing) and batimbangtando (engagement).

Related to that, to examine the local wisdoms of Minangkabau in literary works, especially novels required a literary approach. The most appropriate approach to discuss local wisdom in literary works is the sociology of literature. Sociology of literature is 
an approach that analyzes the social problems contained in the literary work itself, then, connects with the reality that ever happened. The relationship is called reflection (Ratna, 2012: 339).

In addition, Muslimin (2011: 130) explains that literary sociology is an approach that departs from an orientation to the universe, but can also depart from the orientation to the author and the reader.According to the approach of literary sociology, literary worksare seen as related to reality to what extent the literary works reflect reality. The fact here contains broad meaning;either the reality that is outside the literary work or anything referred to literary works.

One novel that reflects the local wisdom of Minangkabau is novel MenguraiRindu by Nang Syamsuddin. Nang Syamsuddin as the author, able to describe Minangkabau local wisdom into the story clearly.NangSyamsuddinn's depiction is able to make readers as if they are in the socio-cultural condition and the mind of the Minangkabau people, and confronted with the customary conflicts that often occur in Minangkabau.

Such socio-cultural condition reflectedin marriage of Lela (the main character in this novel) with Gunawan, male characterwith Chinese descent. Lela's marriage to Gunawan gets a strong rejection from her uncle, AngkuDatuk. AngkuDatuk considers that the marriage of his nephew will be able to decrease the dignity of his people. AngkuDatuk threatened that he would not be present at the marriage ceremony, due to fear of self-esteem as a lost uncle. Lela survives with her stance that she remains married to Gunawan. Lela's marriage to Gunawanis done in the usual manner, in accordance with the prevailing habits in Minangkabau. Starting from the negotiation stage of proposal, which proposed by female family members, batimbangtando(engagement), pernikahan (marriage ceremony), manjapuikmarapulai(picking up the groom) and manjalang (visiting the groom's family). All the ordinances are done by Lela to avoid embarrassment and maintain the dignity of his people.

Based on the description, it is described how the socio-cultural conditions of the Minangkabau community, especially the Minangkabau marriage system consisted of pinang-meminang (proposing), batimbang tando (engagement), pernikahan (wedding), manjapuikmarapulai (picking up the groom), and manjalang (visiting groom's family). Therefore, this study aimed to describe the local wisdom ofMinangkabau's marriage systemin novel MenguraiRindu by Nang Syamsuddin. 


\section{Research Methodology}

The type of research used is qualitative with descriptive method. The data in this research is in the form of words, phrases, clauses, sentences, and paragraphs contained in Nang Syamsuddin's novel MenguraiRindu. The object of this study is the local wisdom of Minangkabau marriage system consisted of pinang-meminang (proposing), batimbang tando (engagement), pernikahan (wedding), manjapuikmarapulai (picking up the groom), and manjalang (visiting groom's family). Sources of data in this study is novel MenguraiRindu by Nang Syamsuddin published by Rahimalntermedia Publishing in 2012 , consists of 243 pages.

Data analysis technique is done by (1) identifying data related to local wisdom of Minangkabau in novel MenguraiRindu by Nang Syamsuddin; (2) classifying the identified data; (3) analyzing data with literature sociology approach; and (4) summarizing the result of data analysis.

\section{Research Resultd An Discussion}

Local wisdom of Minangkabau marriage system consisted of pinang-meminang (proposing), batimbang tando (engagement), pernikahan (wedding), manjapuikmarapulai (picking up the groom), and manjalang (visiting groom's family). The following will be described one by one based on the category.

\subsection{Pinang-Meminang}

In Minangkabau, pinang-meminang(proposing) usually initiated with the female family (Navis, 1986: 199) that is when the bride's familycome to the house of groom'sto propose. In proclaiming the proposal, the women's family would send some men and women to the house of the male family. The envoy led by the woman's uncle.

In novel MenguraiRindu, this event was donewhen Lela's uncle, AngkuDatuk, sent some people to Gunawan's mother's house to declare proposal (proposal). This can be seen in the following quotation.

"Then there is no problem. You set the time. Then later we send some people to come to his mother's house to apply. Do not forget to say this to your daughters-in-law, "this time AngkuDatuk spoke to my Ethek-etek (Syamsuddin, 2014: 68). 
From the data, it appears that uncle Lela, AngkuDatuk send some people come to the house of Gunawan's mother to declare proposal (proposal). This indicates that those who come to marry are the women's family.

Likewise, the proposed party(dipinang), they are willing to wait for the envoy to his home. The successor of the messenger consists of the closest relatives of the family led by uncle. This is reflected in the family of Gunawan's mother by accepting Lela's family who will come to his house. This can be seen in the following quotation:

"My mom's family estimates if your family is coming to propose. Mymom's family is ready to take it. They, mymom's family had promised to help my mom in solving this problem. Mymom really hopes that our marriage will be held soon while my mom family is supportive. If not, it will catch a cold, mymom says. I did not understand what she meant by that. "(Syamsuddin, 2012: 8788).

From the data explained that the awaited messenger who will come to proposeis the mother's family. This is seen in the family of Gunawan's mother, they are ready to accept if the Lela family who came for proposing (married) to his home. The mother's family, in this case represented by a brother of maternal descent called anuncle. The uncle served as a leader when making a proposal.

\subsection{BatimbangTando}

After the pinangan (proposal) accepted by the male family, the next negotiation is to determine the day of engagement will be done. In Minangkabau, this day of engagement is commonly called batimbangtando. Batimbangtando is a sign of exchange that both parties have promised to match their son and daughter in the future. In this batimbangtando, the object to be exchanged is similar in every region. It can be in the form of a gold ring, golden thread cloth (kainpalapak), or inherited keris (Navis, 1986: 199).

In the novel Mengurai Rindu, this batimbangtandoevent first appeared when UdaGadang asked Etehlsan where the eventwas done. Here's the quote.

"Lela", said UdaGadang to me. His voice sounded serious. Today your relationship with Gunawan is official. The family already knows. "OyaTek, where is the TimbangTando, the sign of the engagement?"

"Oh yeah, it's in Lela's room. I put it there,"said Etheklsan. Then he came into my room. When he came out he brought a red jewelry box. 
"You wear the ringnow!" Said EtekBungsu relaxed. "Later," I replied.

"You should wear it now Lela, we want to see. The ring is beautiful with diamond gems. It must be expensive", said EtekBungsu(Syamsuddin, 2012: 94).

From the data, it is seen that Lela andGunawan have done the batimbangtando (engagement). The object that Lela received as an indication of her engagement to Gunawan is a jewelry box in the form of a gold ring. The ring was given by the man to the woman. By batimbangtando(engagement), Lela and Gunawanhave been bound to discussing the next agreement, namely a marriage agreement someday.

According to the Minangkabau custom, if the engagement broke up before the wedding ceremony (the marriage contract), the party decides to return the receipt at the engagement. However, the other party is not obliged to return the receipt (Navis, 1986: 200). It is also found in the novel MenguraiRindu, seen when MakTuah commemorates Lela to not denying the engagement that has been done. Here's the quote:

"Before baralek, you cannot deny your engagement, Lela. If you break our promise,we'll get a fine multiplied two. Do you have any money to buy that diamond ring one more time, Lela? TeasedMakTuah (Syamsuddin, 2012: 97).

From the data it appears that before carrying out baralek or marriage, Lela should not deny her engagement with Gunawan. If that happens,she will get a fine, pay double. Regarding this fine, it is quite diverse each nagari (region) in Minangkabau, according to the Minangkabau proverb that is "lain lubuk lain ikannyo". That is, every region has their own rules or differences in custom according to the conditions of their respective communities.

\subsection{Marriage (AkadNikah)}

After being implemented, batimbangtando (engagement), the next event is the negotiation for the wedding (akadnikah). This marriage is held after the engagement is done. Here's the quote.

"Been engaged, there will be two more events. Akadnikahdanbaralek," EtekIsan remind all people. (Syamsuddin, 2012: 96).

From the data it is seen that Ethan Isan reminds his family that after the engagement (batimbangtando) is done, the next event is the ceremony of marriage. 
In Minangkabau, marapulai (groom) is picked by the messengers of the anakdaro (bride) to the home of his parents. This is an obligation of the bride's family that is illustrated in the following quotation:

"The picking up businessfor marriage must be ascertained first," said EtekTangah (Syamsuddin, 2012: 97).

"Picking up on marriage or baralek is our obligation," Etektangah began to explain what to do next (Syamsuddin, 2012: 98).

From the data, it is seen that EtekTangah is making sure that the picking up event will be done at the marriage contract and wedding ceremony. EtekTangah explained that those who picked upmarapulai (groom) on marriage ceremony is the obligation of her family as the anakdaro's(bride) family. In this case, picking up is done before the marriage contract or marriage ceremony takes place.

Generally, Minangkabau's wedding day held on the afternoon of Thursday night Friday or Friday. They believe that Friday is the best day of the week. The atmosphere of the day is very religious. They chose that day to do all sacred event, like a wedding. This is reflected on the wedding day of Lela and Gunawan which was held on Friday of November. Here's the quote:

"At nine o'clock on Friday morning in November, all the needs associated with the ceremony were ready. EtekTangah has finished checking all items to be brought to pick up the son-in-law to be"(Syamsuddin, 2012: 106).

From the data, it can be seen that Lela and Gunawan's wedding was held on Friday at nine o'clock in the morning before Friday prayers, November. This proves that Lela also believes that Friday is the best day to carry out her marriage, according to the prevailing practice in Minangkabau.

In Minangkabau, after executing a marriage contract or a marriage ceremony; marapulai (groom) cannot directly live in the house of anakdaro (bride). He was brought back by his relatives went home to his parents. He will go to the house of the bride (anakdaro) when picked up customarily by messengers the family of (bride) anakdaro. This can be seen in the following quotation.

"My feelings are beginning to get under control. Slowly,l break away from Gunawan's arms. I'm reluctant to my big family, we're not used to show such feelings. I wiped my tears with the tips of my sleeves. Then,I meet them. I received a few more congratulations. Then the photographer took me and Gunawan to the bridal suite. After shooting several times, Gunawanwas 
invited to his family home. My family let gotheir guests with a sense of pleasure "(Syamsuddin, 2012: 111).

From the data it can be seen that after the wedding image taking process, Gunawan should not directly live at Lela's house. He was invited back by his family to go home. Gunawan will go to Lela's house if the Lela's family picks him up. This is because Lela and Gunawan have only conducted marriage procedures according to syarak(religion), but not yet as Minangkabau'smarriage system. According to Minangkabau's custom, marapulai (groom) may stay together with the (bride) anakdaro, if the marriage has been done according to custom that is after carrying out the wedding ceremony (baralek).

\subsection{ManjapuikMarapulai}

According to Navis, (1986: 204) the most important event in the marriage according to Minangkabau customs is basandiang (sit in site), namely the two bridegroom in marriage for witnessed herbal or guests in attendance. Before basandiang (sit in site), the bride's family must pick up the groom. This is reflected on the Lela's family who will pick up Gunawan to his house on Sunday, at nine o'clock in the morning. Here's the quote.

"That Sunday our job is a bit light. Early in the morning at about nine o'clock we picked the groom to his house" (Syamsuddin 2012: 113).

From the data, it can be seen that manjapuikmarapulai event, which is marked with the phrase "Early in the morning at about nine o'clock we picked the groom to his house". Lela's family picked Gunawan first to his parents' house for wedding ceremony.

The messenger who picked up consisted of women and men. The women's messenger carries the terms of picking up on Tray. In general, inside of Tray is clothes worn by marapulai called Roki. Here's the quote:

"A full groom's outfit. In Padang it's called Roki. In addition, congenital juadah. Has Etek prepared for it? "(Syamsuddin, 2012: 113).

From the data, it explained that the complete clothing of the groom in Padang is Roki. Roki is prepared by the female family as a requirement for picking up. In this case, the Lela family prepares Roki, because Gunawan resides in Padang.

The number of people needed for the event brought by the envoy is reflected in the number of envoys who will come to the house. Based on the number of people needed by Lela's family to bring the requirements for picking up the marapulai to Gunawan's mother's house. This can be seen in the following quotation. 
"Then, surely a lot of people will be needed to take him?"

"Yes, as much as food, along with carano carriers, roki carriers, umbrella carriers and shoes. Has there been someone, Lela? "(Syamsuddin, 2012: 114).

From the data, it is explained that the person needed to pick up accordance with the terms of pick-up, such as a food carrier, Roki, umbrella, and a pair of shoes. If the dress is a loan clothing (rented clothes), then the accompanist is a pair of shoes. In the traditional pick-up, there must be objects brought by the anakdaro (bride) to be used by marapulaiforever.

The messenger who picked up the bride (marapulai) in general is women. Some of them became sumandan. Sumandan means bridesmaids. The sumandan is a young woman who recently married. Normally it is the wife of a close relative. This is reflected in the following quotation:

"Who's gonna be a paumandan (bridesmaid)?

"Des's wife is young " (Syamsuddin, 2012: 114).

From the data, it is seen that the sumandan is a young woman. In this case, the sumandan is the wife of Des. Des is Lela's younger brother, who was recently married, so she was appointed as sumandan whenpicking up marapulai(groom) by Lela's family.

In the custom of picking up the marapulai(groom), anakdaro(bride) is not included. However, based on the results,the agreement between Lela and Gunawan's family, Lela was participated in the event of the manjapuikmarapulai.This is illustrated in the following quotation:

I, the bride, joined in the party of the pickup. The following of the bride in the groom's pick-up was the result of a family agreement, because the wedding was held in the building. So at the time of picking up the bride at once ahead, come, his in-laws (Syamsuddin, 2012: 115).

From the data explained that Lela's participation in picking marapulai is the result of the agreement of both sides of the family because the wedding was held in the building. So when picking up, Lela was also manjalang (vistingthe house-in-law).

In picking upthe marapulai, there is a speech sambahmanyembah from both sides. This speech is done before the meal begins. The host or Si Pangkalet the messenger pick up the meal first before the release of the manjapuikmarapulai event. This is reflected in one of the host men of Gunawan or called the Pangka. The Pangkalet the delegation party of Lela's family to eat dishes that have been provided. Here's the quote: 
"The two groups of men are involved in the conversation. One of my family thrusting a betel vine, the Gunawan family received it. Then they did a small talk. Soon the conversation was over. One of the men asked for Gunawan to use the roki immediately. A woman appeared, took a roki and brought in. Then,some more women came carrying all the merchandise into the inner room. Then the place was fixed quickly. The dish has been neatly arranged, replacing the delivery. Then one of the host men, commonly called "The Pangka " invited our group to eat the dishes available. I heard the speech of UdaGadang stale a bit. Then the meal began (Syamsuddin, 2012: 116-117).

Picking up by the Lela's family is somewhat different from the practice in Padang. Lela's family eliminated the affairs pick up shuttle. According to Padang custom, marapulai(groom) will stay and sleep for the first time at his wife's house, when picked up first by his wife's family messenger in custom. The envoy comprised several young men of his own age who were called rang mudo. Rang mudo's duty is to accompany marapulai (groom) in the house of anakdaro (bride) for the first time. The rangmudo is his daily friend who is still single or married. However, the family of Lela and Gunawan have agreed to eliminate the manjapuikmarapulaievent, as long as it approved by both sides of the family. Here's the quote:

" From that night Gunawan will stay at my house, his wife. Only this part is a bit different implementation. If according to Padang custom, the new bride may sleep at his wife's house the next day after the party. Previously the new groom was picked up by the family of women to the home of her parents. However, this time agreed to take a simple course only. The picking up event was removed. The proposal was approved by both parties. (Syamsuddin, 2012: 120).

From the data, it is explained that marapulai (groom) can sleep first at his wife's house, when picked first by the family of the customary family to the house of their master, called rang mudo.

\subsection{Manjalang}

Manjalang (visiting) is visiting the in-law's family (Navis, 1986:206). The groom's family wait for the bride to come for visiting. The purpose of doing this manjalang is to fill the custom after the marriage contract from the family of anakdaroto the family side marapulai. Filling this custom means that the family of anakdaro on the wedding day 
must come formally to the family home to know the family of son-in-law. At the time of the manjalang (visiting), the bride and groom depart from the house of anakdaro (bride), they walked side by side with their best clothes, accompanied by relatives of anakdaro, and behind him the woman who tipjambar on the head. This is reflected in the procession of manjalang by the Lela family to the house Gunawan's mom. Here's the quote:

"At eleven o'clock on that Sunday, my family arrived at Gunawan's house. For a moment, we stood in the courtyard, arranging a row of entourage. I was at the front, sandwiched between two men and women. Behind me, stood a woman's family carrying the goods. In the back row, lined up several male families. All is arranged quickly, because KakTuo, UdaGadang's wife has reminded them from home. (Syamsuddin, 2012: 115).

From the quotation is seen that the family Lela manjalang to home momGunawan. Before boarding the house of marapulai, EtekTangah is arranging a row of entourage first. Lela as a anakdaro is at the front by flanked by two sumandan. Behind him stood a women's family carrying goods. And in the back row again lined up some men, who became spokesmen.

Arriving at home marapulai, Lela and his entourage watered with turmeric rice, then all the entourage is welcome to ride home by the relatives of marapulai. According to Minangkabau people's belief, the purpose of the two brides doused with turmeric rice is to give blessing. This can be seen in the following quotation:

"Guests are ready. Some women are wearing bajukurung (long sleeves) and wear songket (skirt) waiting at the door. Some men dressed in batikare seen accompanying. Then one of the women came forward. He sprinkled the turmeric rice on our group, then invited all into the house. (Syamsuddin, 2012: 115-116).

From the data, it is seen that one of the relatives sprinkling turmeric rice on Lela and his entourage. After the event was finished, then all the entourage invited up to the house begins. The bride and groom will be led up the stairs by the sumandan marapulai, then seated in the aisle, accompanied by sumandan(bridesmaid).

"I was seated under the aisle, accompanied by both pasumandan. The other entourage sat around the dish. Goods have been neatly arranged in the pelaminan deliberately emptied by the host. UdaGadang and Angku Sati sat on the right of the aisle, facing the delivery. On the other side, on the left, there are also two men from the family Gunawan. (Syamsuddin, 2012: 116). 
From the data, it is seen that Lela is seated under the aisle, which is accompanied by both pasumandan. In Minangkabau, their purpose is seated in the aisle to introduce to the members and the guests that there is a new bond between the members of the people.

\section{Conclusion}

Based on the analysis, some conclusions can be drawn as follows: First, the local wisdom Minangkabau marriage system based on novel MenguraiRindu by Nang Syamsuddin consist of (1) pinang-meminang (proposing), the bride's family will come to propose the groom that the uncle of the bride will be in charge of the proposal system. (2) Batimbangtando (engagement) is when the agreement made between two parties; those who break the vows must pay the fine as much as the first agreement multiplied two. (3) Pernikahan (wedding), some believes that Friday is the best day to carry out the marriage contract. After the marriage ceremony, the groom will return to the home of his parents. (4) Manjapuikmarapulai (picking up the groom), that is when the bride's family picked up the groom along with Roki (complete outfit for groom), a pair of shoes, and the existence of pasumandan (uncle's wife of the bride). (5)Manjalang (visiting groom's family) is the procedure and tradition of watering turmeric rice on the bride during the procession of manjalang. The local wisdom of Minangkabau is a careful painting of the socio-cultural conditions of the Minangkabau community. The socio-cultural conditions of the Minangkabau community are characterized among others as seen in the system of marriage. It can be concluded that the Minangkabau marriage system in novel MenguraiRindu by Nang Syamsuddin consisted of pinang-meminang (proposing), batimbangtando (engagement), pernikahan (wedding), manjapuikmarapulai (picking up the groom), and manjalang (visiting groom's family) should be retained as local wisdom.

\section{Suggestion}

Based on these conclusions, the author's suggestion is: (1) To other researchers or prospective researchers of literature, to be able to describe other Minangkabau local wisdoms, by means of different approaches or research objects, thus contributing widely to maintain and promote the Minangkabau local wisdom to the reader. (2) To the reader, the result of this research can be used as information material to add new insight and knowledge about Minangkabau local wisdom. (3) To the Guru, novels MenguraiRindu by Nang Syamsuddincan be used as an interesting learning media to introduce local 
wisdom Minangkabau, especially about Minangkabau marriage implementation system to students in school.

\section{References}

[1] Kurnia, Maya Dewi. 2017. "Malay Local Wisdom on Novel Ayah Karya Andrea Hirata" Deiksis - Indonesian Language and Literature Education Journal, Volume 4, No. 2, p. 141.

[2] Kusmarwanti. 2008. LocalWisdom ofMinangkabau in Indonesian Literature Works. Paper Seminar PIBSI in Magelang.

[3] Moleong, Lexy J. 2010. Qualitative Research Methodology. Jakarta: Teens Rosdakarya.

[4] Muslimin. 2011. "Modernization in the Novel Shackles of Armijn Pane's Work" Language, literature,and Culture, Volume 1, No. 1, p. 130.

[5] Nurgiyantoro, Burhan. 2010. Fictional Studies Theory . Yogyakarta: GadjahMada University Press.

[6] Navis, AA 1986 . The Developed Realm Became Indigenous Teachers and MinangkabauCulture . Jakarta: Graphite Library.

[7] Ratna, NyomanKutha. 2012. Theory, Methods, and Techniques of Literature Research . Yogyakarta: Student Literature.

[8] Syamsuddin, Nang. 2012. Breaking Rindu . Yogyakarta: Rahimalntermedgia Publishing. 